\title{
PEMAHAMAN MAHASISWA TENTANG INTEGRAL LIPAT DUA BERDASARKAN TEORI APOS
}

\author{
Agus Supriadi \\ Program Studi Pendidikan Matematika Universitas Muhammadiyah Palembang \\ agussupriadiump81@gmail.com
}

\begin{abstract}
ABSTRAK
Integral lipat dua merupakan integral suatu fungsi dua variabel terhadap luasan di $\mathrm{R}^{2}$. Tujuan penelitian ini untuk mendeskripsikan pemahaman mahasiswa Program Studi Pendidikan Matematika Universitas Muhammadiyah Palembang Tahun Akademik 2020/2021 tentang materi integral lipat dua berdasarkan teori APOS. Subjek penelitian adalah mahasiswa semester 4 Program Studi Pendidikan Matematika Universitas Muhammadiyah Palembang Tahun Akademik 2020/2021 yang berjumlah 9 orang. Data hasil tes dan wawancara dianalisis secara deskriptif kualitatif untuk menggambarkan pemahaman mahasiswa tentang konsep integral lipat dua berdasarkan teori APOS. Hasil penelitian diperoleh bahwa kemampuan pemahaman mahasiswa terhadap materi integral lipat dua berdasarkan teori APOS adalah sebagai berikut: 4 orang tidak sampai pada tahap aksi, 2 orang mahasiswa pada tahap aksi, dan 3 orang pada tahap skema. Temuan dalam penelitian ini adalah pemahaman mahasiswa tentang konsep integral lipat dua berdasarkan teori APOS masih rendah. Sebagian besar pemahaman mahasiswa tidak sampai atau hanya berada pada level terendah dari tahap APOS. Oleh karena itu, diperlukan kajian lebih lanjut agar pemahaman mahasiswa dapat meningkat.
\end{abstract}

Kata kunci : integral lipat dua, teori APOS

\begin{abstract}
The integral of a function of two variables with respect to the area in R2 is known as the double integral. The goal of this study was to describe students' understanding of the double integral material based on the APOS theory in the 2020/2021 academic year at the University of Muhammadiyah Palembang's Mathematics Education Study Program. The research participants were 9 fourth semester students from the Mathematics Education Study Program at the Universitas Muhammadiyah Palembang for the Academic Year 2020/2021. Based on the APOS theory, the test and interview data were analyzed descriptively and qualitatively to describe students' understanding of the concept of a twofold integral. According to the findings, the students' ability to comprehend the twofold integral material based on the APOS theory was as follows: Four students did not advance to the action stage, two advanced to the action stage, and three advanced to the schema stage. According to the findings of this study, students' understanding of the concept of a twofold integral based on APOS theory is still poor. The majority of students' comprehension does not reach or is only at the lowest level of the APOS stage. As a result, future research is required to improve student comprehension.
\end{abstract}

Keywords : double integral, APOS theory 


\section{PENDAHULUAN}

Integral lipat dua merupakan integral suatu fungsi dua variabel terhadap luasan di R2 (Stewart, 2010). Pemahaman mahasiswa terhadap integral lipat dua akan menentukan pemahaman mahasiswa pada materi selanjutnya dan bahkan mata kuliah lainnya seperti Geometri Analitik (Utari, Septy, dan Hutauruk, 2021). Namun, dalam proses pembelajarannya banyak mahasiswa mengalami kesulitan dalam memahami materi ini (Apriandi dan Krisdiana, 2016; Kwan, 2017).

Kesulitan mahasiswa dalam memahami konsep integral lipat dua dapat dianalisis lebih lanjut dengan menghubungkannya dengan teori belajar. Konsep matematika, termasuk konsep integral lipat dua dapat dikonstruksi menggunakan teori APOS (Aksi-Proses-Objek-Skema). Teori ini mengemukakan bagaimana seseorang dapat mengkonstruksi suatu konsep matematika. Teori ini dikembangkan oleh Dubinsky dan koleganya sejak tahun 1991. Lebih lanjut Dubinsky dan McDonald (2001) menjelaskan bahwa teori APOS dapat digunakan untuk membandingkan keberhasilan dan kegagalan mahasiswa dalam mengkonstruksi suatu konsep matematika.

Analisis pemahaman siswa terhadap konsep matematika berdasarkan teori APOS telah banyak dilakukan oleh peneliti sebelumnya. Fitrianti, Suryadi, dan Kusnandi (2020) melakukan analisis kesulitan mahasiswa calon guru dalam menyelesaikan permasalahan keterbagian bilangan berdasarkan teori APOS. Analisis pemahaman siswa tentang grafik fungsi kuadrat berdasarkan teori APOS oleh Listiawati dan Juniati (2021), fungsi satu variabel (Chimhande, Naidoo, dan Stols, 2017), limit fungsi (Afgani, Suryadi, dan Dahlan, 2017), turunan implisit (Borji dan Martínez-Planell, 2020), persamaan diferensial biasa (Ningsih dan Rohana, 2018), integral Riemann (Tokgoz, 2016), dan koordinat polar (Borji, Erfani, dan Font, 2020).

Analisis pemahaman mahasiswa terhadap materi matematika tersebut, termasuk materi integral lipat dua ini penting untuk dilakukan. Hal ini merupakan bagian dari evaluasi dan refleksi dari pembelajaran, sehingga dapat digunakan oleh guru untuk melakukan perancangan pembelajaran yang akan datang (Raupu, Thalhah, dan Mattoliang, 2020). Meskipun analisis pemahaman mahasiswa tentang materi integral lipat dua telah banyak dikaji, namun analisis pemahaman berdasarkan teori APOS belum pernah dilakukan.

Penelitian ini bertujuan untuk mengetahui kemampuan pemahaman konsep matematis mahasiswa pada materi Integral Lipat Dua berdasarkan teori APOS. Informasi yang didapatkan dari penelitian ini diharapkan dapat memberikan manfaat bagi dosen untuk menemukan pendekatan pembelajaran yang tepat dalam membantu mahasiswa untuk memahami materi ini, serta secara umum dapat meningkatkan kualitas pembelajaran matematika.

Pemahaman seseorang terhadap suatu konsep matematika dapat dikonstruksi dengan tahapan APOS sebagai berikut (Dubinsky \& McDonald, 2001): (1) Aksi: transformasi dari objek matematika yang dilakukan oleh seseorang meliputi langkahlangkah prosedur atau operasi matematika. (2) Proses: tahap aksi yang dilakukan berulang dan seseorang melakukan refleksi maka dapat membentuk konstruksi mental internal. (3) Objek: tahap proses yang disadari oleh seseorang dan dapat menginteriosasi proses, sehingga dapat menunjukkan pemahaman terhadap suatu konsep. (4) Skema: kumpulan dari aksi, proses, objek lainnya yang terhubung secara padu dan diorganisasi secara terstruktur dalam pikiran individu. 
Berdasarkan penjelasan tahap APOS tersebut, pemahaman seseorang untuk materi Integral Lipat Dua dapat dijelaskan sebagai berikut: Tahap Aksi ditunjukkan oleh kemampuan mahasiswa dalam menentukan batas integrasi. Selanjutnya, pemahaman mahasiswa pada tahap Proses ditunjukkan oleh kemampuan mahasiswa dalam menentukan formula untuk menyelesaikan permasalahan integral lipat dua. Interiosasi konsep dilakukan mahasiswa dalam menentukan batas integrasi, menentukan variabel mana yang lebih dahulu diselesaikan, kemudian menyelesaikan perhitungan integral lipat dua membentuk suatu Objek. Pemahaman pada tahap Skema yaitu mahasiswa telah memahami konsep integral lipat dua secara menyeluruh setelah melalui tahap Aksi-Proses-Objek. Mahasiswa pada tahap ini mampu menjelaskan konsep-konsep terkait penyelesaian masalah integral lipat dua.

\section{METODE}

Penelitian ini merupakan penelitian deskriptif. Tujuan penelitian ini untuk mendeskripsikan pemahaman mahasiswa Program Studi Pendidikan Matematika Universitas Muhammadiyah Palembang Tahun Akademik 2020/2021 tentang materi integral lipat dua berdasarkan teori APOS. Subjek penelitian adalah mahasiswa semester 4 Program Studi Pendidikan Matematika Universitas Muhammadiyah Palembang Tahun Akademik 2020/2021 yang berjumlah 9 orang. Data diperoleh dengan mengadakan tes tertulis dan wawancara. Tes berupa soal essay terstruktur mengenai integral lipat dua yang memuat indikator teori APOS dan wawancara dilakukan secara lisan kepada subjek penelitian untuk menggali lebih dalam tentang pemahaman subjek terhadap materi integral lipat dua. Soal tes merupakan soal yang dirancang sesuai dengan indikator teori APOS dengan rincian seperti pada Gambar 1 berikut:

\section{Soal 1}

Gambar berikut menunjukkan suatu daerah $\mathrm{D}$ yang dibatasi oleh sumbu $\mathrm{x}$, sumbu y dan garis $y=x$

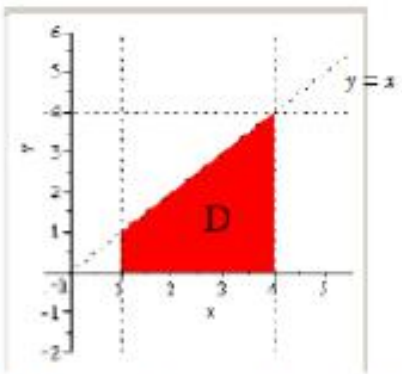

1.a) Tentukan batasan daerah $D$. (A)

1.b) Hitunglah luas daerah D. (A, P dan O)

Gambar 1. Soal integral lipat dua

Selanjutnya, data hasil tes dan wawancara dianalisis secara deskriptif kualitatif untuk menggambarkan pemahaman mahasiswa tentang konsep integral lipat dua berdasarkan teori APOS. Wawancara bertujuan untuk menggali lebih jauh pemahaman konsep mahasiswa termasuk letak kesulitan dan faktor-faktor penyebabnya. 


\section{HASIL DAN PEMBAHASAN}

Penelitian ini mendeskripsikan kemampuan mahasiswa terhadap konsep integral lipat dua berdasarkan teori APOS. Pelaksanaan tes dilakukan pada hari Kamis, tanggal 29 Juli 2021. Soal tes terdiri dari 1 soal yang mengukur kemampuan pemahaman integral lipat dua berdasarkan teori APOS. Pemahaman mahasiswa ini diketahui dari hasil analisis jawaban mahasiswa terhadap soal. Pada soal disediakan suatu grafik luas wilayah D dengan batasan tertentu. Mahasiswa harus dapat menentukan batasan wilayah dengan tepat, kemudian menentukan formulasi integral lipat dua dan menyelesaikan integral lipat dua tersebut. Hasil jawaban mahasiswa untuk soal 1 dapat dilihat pada Tabel 1 .

Tabel 1. Pemahaman mahasiswa terhadap integral lipat dua berdasarkan teori APOS

\begin{tabular}{|c|c|c|c|c|c|}
\hline Subjek & $\mathrm{A}$ & $\mathrm{P}$ & $\mathrm{O}$ & $\mathrm{S}$ & Indikator level teori APOS \\
\hline S1 & & & & $\mathrm{X}$ & $\begin{array}{l}\text { Dapat menentukan batasan wilayah } \\
\text { Dapat membuat formula untuk menentukan luas } \\
\text { wilayah } \\
\text { Dapat menyelesaikan perhitungan luas wilayah } \\
\text { dengan menggunakan konsep integral lipat dua }\end{array}$ \\
\hline S2 & $\mathrm{X}$ & & & & Dapat menentukan batasan wilayah \\
\hline S3 & - & & & & Tidak ada indikator yang terpenuhi \\
\hline S4 & & & & $\mathrm{X}$ & $\begin{array}{l}\text { Dapat menentukan batasan wilayah } \\
\text { Dapat membuat formula untuk menentukan luas } \\
\text { wilayah } \\
\text { Dapat menyelesaikan perhitungan luas wilayah } \\
\text { dengan menggunakan konsep integral lipat dua }\end{array}$ \\
\hline S5 & - & & & & Tidak ada indikator yang terpenuhi \\
\hline S6 & - & & & & Tidak ada indikator yang terpenuhi \\
\hline S7 & & & & $\mathrm{X}$ & $\begin{array}{l}\text { Dapat menentukan batasan wilayah } \\
\text { Dapat membuat formula untuk menentukan luas } \\
\text { wilayah } \\
\text { Dapat menyelesaikan perhitungan luas wilayah } \\
\text { dengan menggunakan konsep integral lipat dua }\end{array}$ \\
\hline S8 & - & & & & Tidak ada indikator yang terpenuhi \\
\hline S9 & $\mathrm{X}$ & & & & Dapat menentukan batasan wilayah \\
\hline
\end{tabular}

Berdasarkan hasil pada Tabel 1 diketahui bahwa ada 4 orang mahasiswa yang pemahamannya terhadap integral lipat dua tidak sampai pada tahap Aksi. Mahasiswa yang ada pada kategori ini adalah S3, S5, S6 dan S8. Mahasiswa ini telah mencoba untuk menyelesaikan permasalahan, namun karena konsep-konsep pendukung untuk integral lipat dua masih lemah, maka mahasiswa tidak dapat menyelesaikan permasalahan dengan benar. Contoh jawaban mahasiswa S5 dapat dilihat pada Gambar 2. 


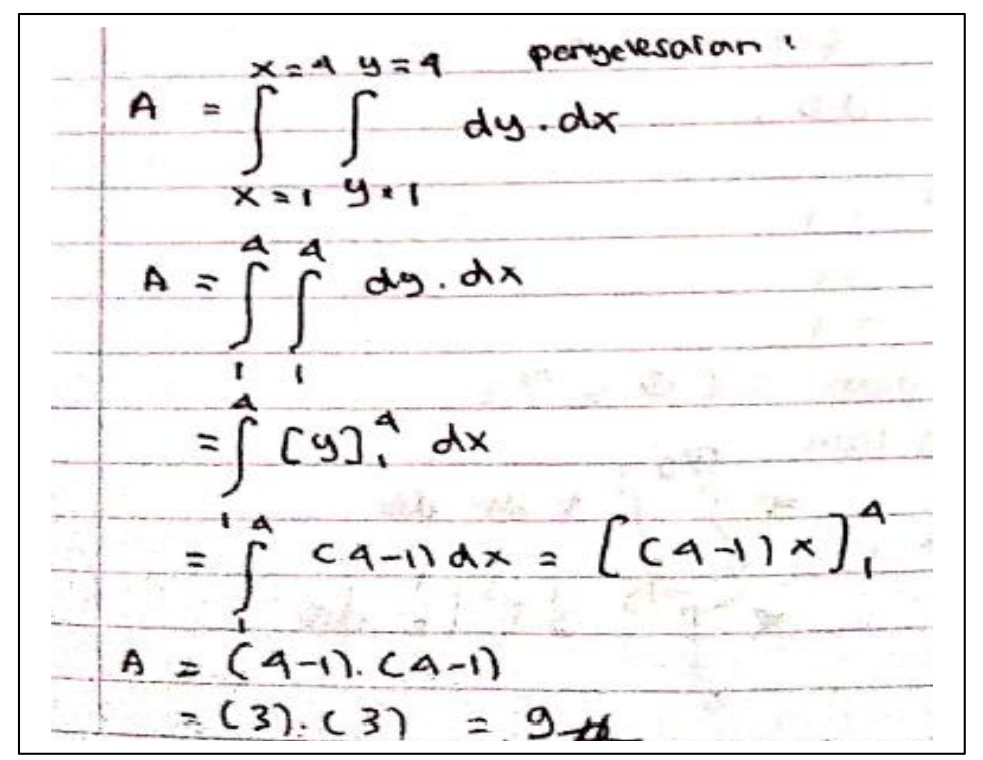

Gambar 2. Jawaban S5

Berdasarkan jawaban S5 diketahui bahwa terdapat kesalahan dalam menentukan batasan wilayah. S5 menuliskan bahwa luas wilayah D pada sumbu dibatasi oleh $y_{1}=1$ dan $y_{2}=4$. Untuk sumbu y batas wilayah seharusnya adalah $y_{1}=1$ dan $y_{2}=x$. Batas pada sumbu y ini merupakan suatu persamaan garis bukanlah suatu koordinat kartesius. Hal inilah yang menjadi faktor penyebab kesalahan mahasiswa. Setelah dilakukan wawancara lebih lanjut, mahasiswa ini tidak memahami batasan wilayah dengan tepat.

Kesalahan mahasiswa dalam menentukan batas integrasi merupakan bagian dari kesalahan konsep (Fahrudin, 2018). Selain itu kemampuan membaca atau memahami koordinat kartesius, persamaan garis pada suatu grafik dalam menyelesaikan luas daerah masih rendah. Kesalahan ini sama halnya dengan yang disebutkan oleh Muchlis (2017) dan Putri dan Nadlifah (2021). Kemampuan untuk dapat memahami atau membaca grafik dengan benar dari suatu fungsi merupakan kemampuan dasar yang harus dipahami mahasiswa untuk dapat mempelajari materi integral lipat dua. Oleh karena itu, mahasiswa yang kurang memahami grafik fungsi akan kesulitan dalam menyelesaikan permasalahan integral lipat dua.

Selanjutnya, ada 2 mahasiswa yang pemahamannya sampai pada tahap Aksi, yaitu S2 dan S9. Mahasiswa pada tahap ini telah dapat menentukan batasan wilayah dengan benar. Namun dalam menyelesaikan permasalahan integral lipat dua mahasiswa tersebut masih kurang paham dengan metode pengintegralannya. Contoh jawaban mahasiswa S2 pada tahap Aksi dapat dilihat pada Gambar 3. 


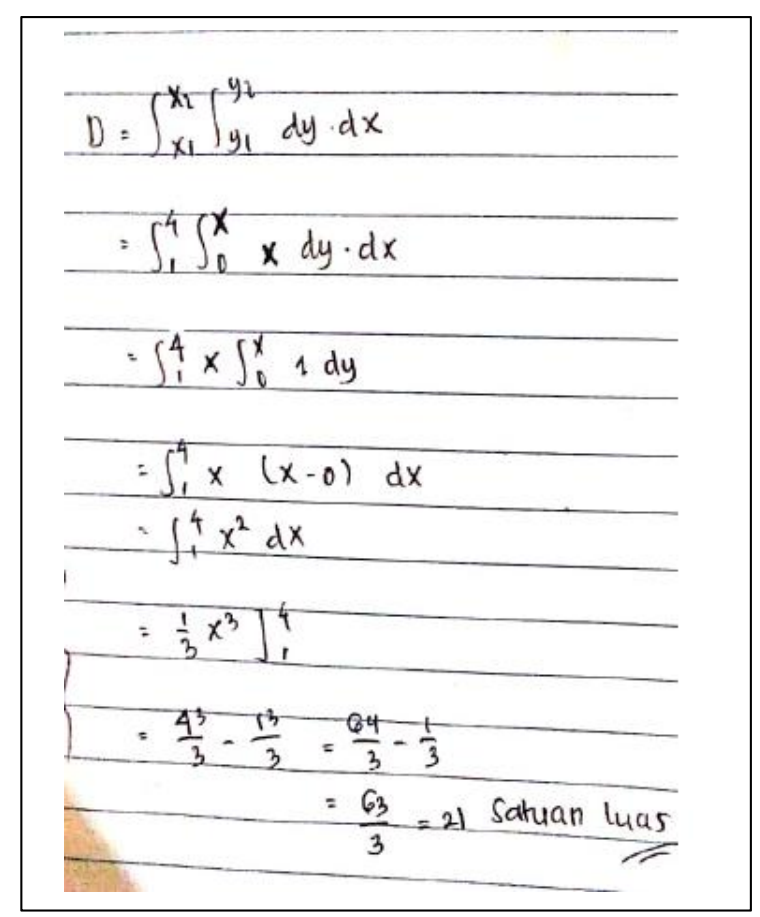

Gambar 3. Jawaban S2

Berdasarkan jawaban S2 pada Gambar 3 tersebut diketahui bahwa S2 menuliskan batasan wilayah integrasi dengan benar. Akan tetapi penulisan rumus atau formula untuk menghitung penyelesaian integral lipat dua masih salah. Dalam hal ini, S2 mencoba untuk memisahkan variabel $\mathrm{x}$ dan variabel $\mathrm{y}$, yang seharusnya tidak dipisahkan namun diperhatikan variabel mana yang harus diselesaikan terlebih dahulu. Oleh karena itu, konsep integral lipat dua belum dipahami secara baik oleh S2. Tahap proses dimana mahasiswa mampu untuk menentukan formulasi dan perhitungan dalam menyelesaikan masalah integral lipat dua tidak dapat dicapai oleh $\mathrm{S} 2$.

Kemampuan untuk membuat rumus untuk mencari luas wilayah dari grafik yang diketahui termasuk dalam kemampuan berpikir tingkat tinggi yaitu menganalisis. Kesalahan dalam menganalisis dan membuat formulasi ini termasuk dalam kesalahan prosedur (Fahrudin, 2018). Mahasiswa banyak mengalami kesulitan dalam memahami soal non rutin dalam penerapan integral lipat dua (Nurmalitasari, 2017).

Selanjutnya adalah pemahaman mahasiswa terhadap materi integral lipat dua sebagai Objek. Pada tahap ini mahasiswa dapat menginteriosasi tahap Proses sehingga menjadi suatu kumpulan konsep yang dipahami oleh individu. Tahap ini ditunjukkan dengan kemampuan mahasiswa dalam menyelesaikan permasalahan integral lipat dua. Tahap Objek berlanjut ke tahap Skema apabila individu dapat memberikan penjelesan mengenai konsep atau Objek yang telah dipahaminya. Skema yaitu tahap dimana mahasiswa dapat menyelesaikan permasalahan integral lipat dua dengan benar dan dapat memberikan penjelasan. Ada 3 orang mahasiswa yang sampai pada tahap ini yaitu S1, S4, dan S7. Contoh jawaban S1 dan S4 untuk soal 1 disajikan pada Gambar 4 dan Gambar 5. 


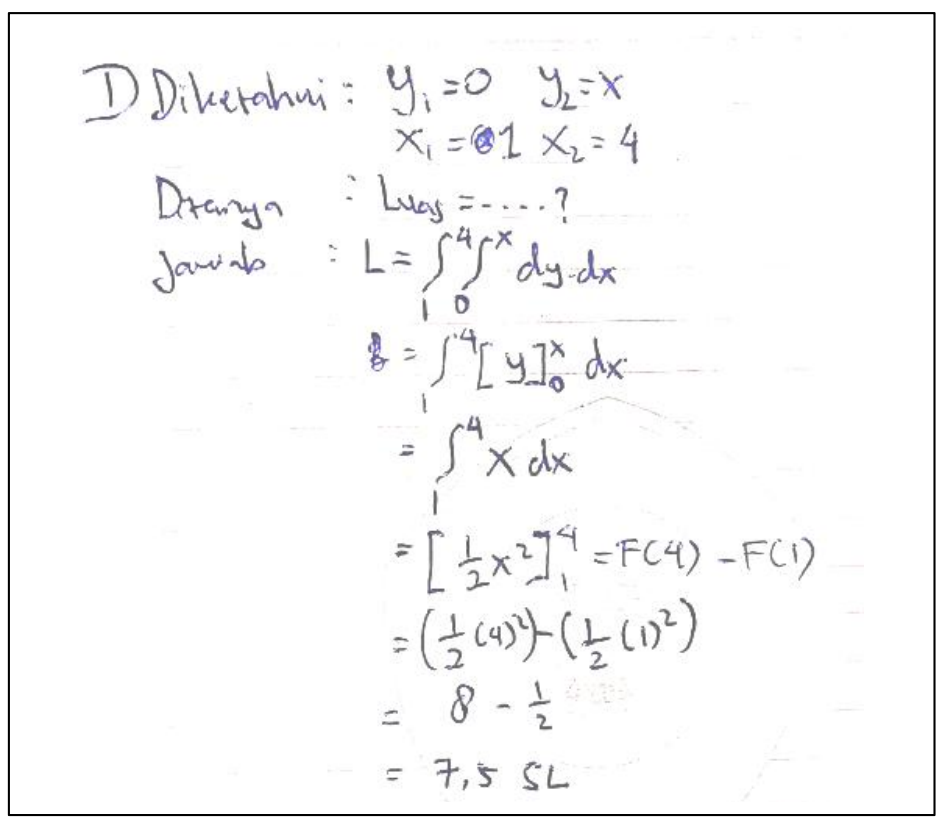

Gambar 4. Jawaban S1

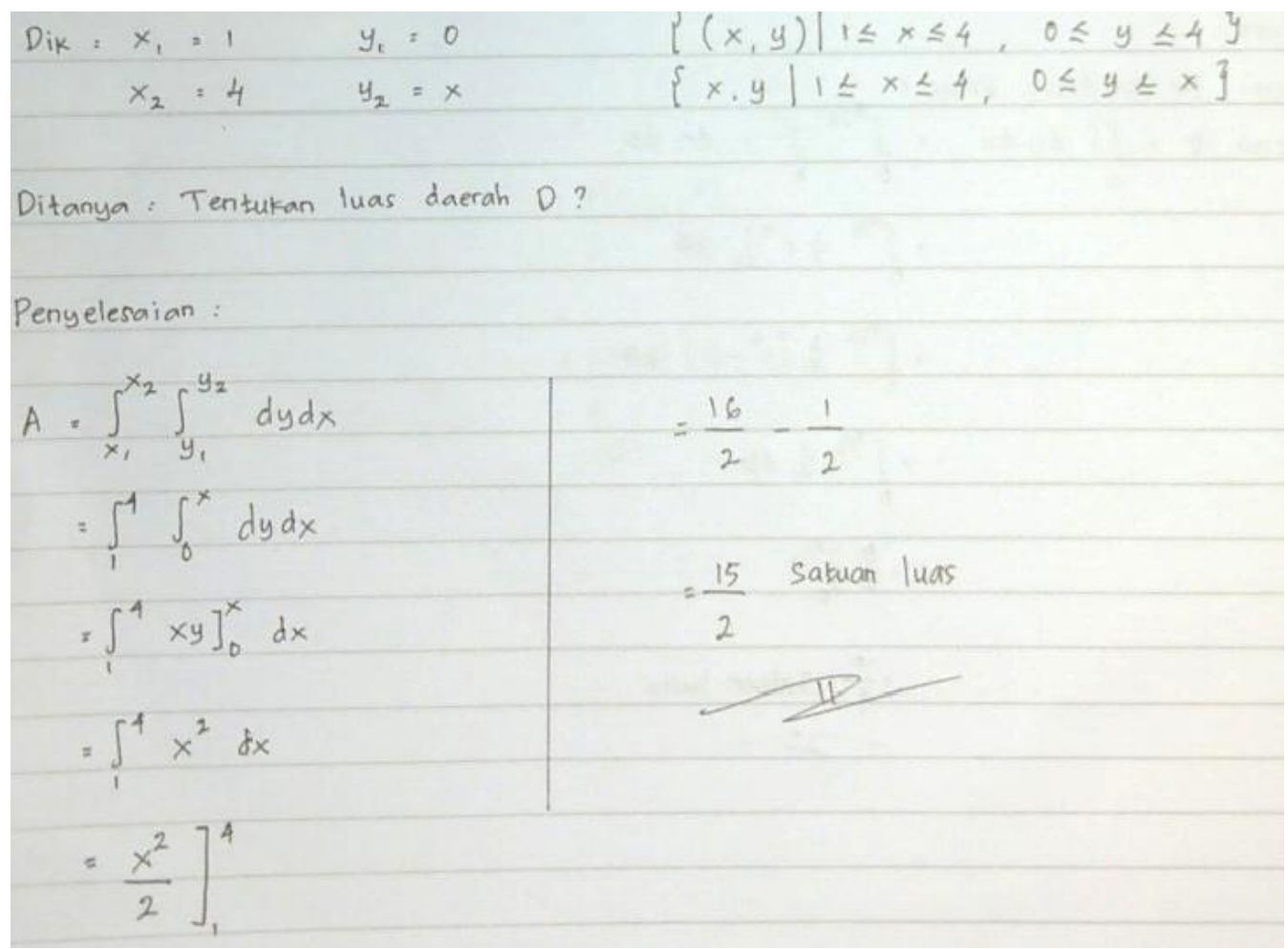

Gambar 5. Jawaban S4

Berdasarkan Gambar 4 dan 5 diketahui bahwa S1 dan S4 menjawab permasalahan dengan benar. Dengan demikian pemahaman mahasiswa telah sampai pada tahap Objek. Pada tahap ini mahasiswa dapat menerapkan konsep-konsep terkait integral lipat dua yang dipahaminya untuk menentukan solusi. Mahasiswa dapat membaca grafik dengan benar, mengetahui batasan wilayah pada koordinat 
kartesius dengan benar, menerapkan formulasi integral lipat dua dengan benar dan mampu menyelesaikan perhitungan untuk menentukan luas wilayah dengan benar.

Selanjutnya untuk menentukan apakah pemahaman S1, S4 dan S7 juga sampai pada tahap Skema, dilakukan wawancara secara lisan. Hasil wawancara dengan ketiga subjek tersebut menunjukkan bahwa pemahaman mereka sampai pada tahap Skema. Subjek dapat menjelaskan langkah-langkah yang dilakukan dalam menyelesaikan permasalahan integral lipat dua dengan tepat.

\section{SIMPULAN DAN SARAN}

Berdasarkan hasil penelitian diketahui bahwa kemampuan pemahaman mahasiswa terhadap materi integral lipat dua berdasarkan teori APOS adalah sebagai berikut: 4 orang mahasiswa pemahamannya tidak sampai pada tahap aksi, 2 orang mahasiswa yang pemahamannya sampai pada tahap aksi, dan 3 orang mahasiswa yang pemahamannya sampai pada tahap skema. Temuan dalam penelitian ini adalah pemahaman mahasiswa tentang konsep integral lipat dua berdasarkan teori APOS masih rendah. Sebagian besar pemahaman mahasiswa tidak sampai atau hanya berada pada level terendah dari tahap APOS. Oleh karena itu, perlu dilakukan tindakan lebih lanjut agar pemahaman mahasiswa bisa mencapai pada tahap skema.

\section{DAFTAR PUSTAKA}

Afgani, M. W., Suryadi, D., and Dahlan, J. 2017. Analysis of Undergraduate Students' Mathematical Understanding Ability of the Limit of Function Based on APOS Theory Perspective. Journal of Physics : Conference Series, 895(1):012056: 1-7.

Apriandi, D. dan Krisdiana, I. 2016. Analisis Kesulitan Mahasiswa dalam Memahami Materi Integral Lipat Dua Pada Koordinat Polar Mata Kuliah Kalkulus Lanjut. Al-Jabar: Jurnal Pendidikan Matematika, Vol. 7(2) : 123134.

Borji, V., Erfani, H., and Font, V. 2020. A Combined Application of APOS and OSA to Explore Undergraduate Students' Understanding of Polar Coordinates. International Journal of Mathematical Education in Science and Technology, Vol. 51(3) : 405-423.

Borji, V. and Martínez-Planell, R. 2020. On Students' Understanding of Implicit Differentiation Based on APOS Theory. Educational Studies Mathematics, Vol. 105(2) : 163-179.

Chimhande, T., Naidoo, A., and Stols, G. 2017. An Analysis of Grade 11 Learners' Level of Understanding of Functions in Terms of Apos Theory. Africa Education Review, Vol. 14(3-4) : 1-19.

Dubinsky, E. and McDonald, M. A. 2001. APOS: A Constructivist Theory of Learning in Undergraduate Mathematics Education Research. The Teaching and Learning of Mathematics at University Level, Vol. 7(3) : 275-282.

Fahrudin, F. A. 2018. Identifikasi Kesalahan Mahasiswa dalam Menyelesaikan Soal Kalkulus Peubah Banyak Berdasarkan Taksonomi Solo. Jurnal Pendidikan Matematika Indonesia, Vol. 3(1) : 7-14.

Fitrianti, Y., Suryadi, D., and Kusnandi. 2020. Analysis of Difficulties for PreService Mathematics Teacher in Problem Solving of Division and Divisibility 
Based on Theory of Action, Process, Object, and Schemes. Journal of Physics: Conference Series, Vol. 1521(3) : 1-6.

Kwan, C. L. C. 2017. Findings from The Assessment of Students' Learning Outcomes in Engineering Mathematics. International Journal of Learning and Teaching, Vol. 9(2) : 291-297.

Listiawati, E. and Juniati, D. 2021. An APOS Analysis of Student's Understanding of Quadratic Function Graph. Journal of Physics : Conference Series, 1747 $012028: 1-9$.

Muchlis, E. E. 2017. Analisis Kesalahan Mahasiswa pada Materi Integral Lipat di Prodi Pendidikan Matematika FKIP Universitas Bengkulu. Seminar Matematika dan Pendidikan Matematika Universitas Negeri Yogyakarta. Hal: 265-272. ISBN. 978-602-73403-2-9.

Ningsih, Y. L. dan Rohana. 2018. Pemahaman Mahasiswa terhadap Persamaan Diferensial Biasa Berdasarkan Teori APOS. Jurnal Penelitian dan Pembelajaran Matematika (JPPM), Vol. 11(1) : 168-176.

Nurmalitasari, D. 2017. Analisis Kesulitan Belajar Mahasiswa pada Mata Kuliah Kalkulus Peubah Banyak di STKIP PGRI Pasuruan. Educazione, Vol. 5(1) : 27-34.

Putri, O. R. U. dan Nadlifah, M. 2021. Proses Transformasi Visual ke Simbolik Mahasiswa dalam Menyelesaikan Masalah Luas Daerah di Bawah Kurva. Jurnal Elemen, Vol. 7(2) : 425-437.

Raupu, S., Thalhah, S. Z., and Mattoliang, L. A. 2020. Learning Difficulties in Solving Calculus Tests. MaPan : Jurnal Matematika dan Pembelajaran, Vol. $8(2): 168-178$.

Stewart, J. 2010. Calculus: Early Transcendentals, 7th ed. Belmont: Brooks/Cole.

Tokgoz, E. 2016. Evaluation of Engineering \& Mathematics Majors' Riemann Integral Definition Knowledge by Using APOS Theory. ASEE's 123rd Annual Conference and Exposition, paper ID 14461. New Orleans, LA.

Utari, R. S., Septy, L., dan Hutauruk, L. 2021. Kesalahan Pemahaman Konsep Peserta Didik dalam Menyelesaikan Soal-soal Integral Lipat Dua pada Koordinat Polar. Inovasi Matematika, Vol. 3(1) : 51-61. 